\title{
Giulia Vicini, The Dublin Regulation Between Strasbourg and Luxembourg: Reshaping "Non-Refoulement" in the Name of Mutual Trust? (Rozporządzenie dublińskie między Strasburgiem i Luksemburgiem: nowe ukształtowanie zasady non-refoulement $w$ imię wzajemnego zaufania?), "European Journal of Legal Studies" 2015, vol. 8, no. 2, s. 50-72, ISSN 1973-2937.
}

Artykuł poświęcony jest kwestii zgodności tzw. systemu dublińskiego z chronionymi w prawie międzynarodowym i europejskim prawami podstawowymi. Głównym filarem systemu jest obecnie Rozporządzenie Parlamentu Europejskiego i Rady (UE) nr 604/2013 z dnia 26 czerwca 2013 r. w sprawie ustanowienia kryteriów i mechanizmów ustalania państwa członkowskiego odpowiedzialnego za rozpatrzenie wniosku o udzielenie ochrony międzynarodowej złożonego w jednym z państw członkowskich przez obywatela państwa trzeciego lub bezpaństwowca (tzw. Rozporządzenie Dublin III), które zastąpiło dotyczące tej samej materii Rozporządzenie Rady (WE) 343/2003 z dnia 18 lutego 2003 r. (tzw. Rozporządzenie Dublin II). Jako pretekst do podjęcia rozważań autorka wskazuje orzeczenie Europejskiego Trybunału Praw Człowieka (ETPC) w sprawie Tarakhel przeciwko Szwajcarii (sprawa 29217/12) z 4 listopada $2014 \mathrm{r}$.

W pierwszej części artykułu scharakteryzowane zostało znaczenie rozporządzenia dublińskiego w unijnym prawie azylowym. Dokument ten zawiera hierarchicznie uszeregowane, obiektywne kryteria pozwalające wskazać państwo, które rozpatrzy wniosek o udzielenie statusu uchodźcy złożony w jednym z nich. Mechanizm dubliński implikuje niemożność złożenia wniosku w kolejnym państwie, jeżeli został on już odrzucony w państwie odpowiedzialnym w świetle kryteriów dublińskich. Jeżeli natomiast okaże się, że w myśl przepisów rozporządzenia odpowiedzialne za rozpatrzenie wniosku jest państwo inne niż to, w którym wniosek został złożony, aplikant zostaje do niego przekazany.

Kluczową kwestią jest to, że mechanizm dubliński opiera się na założeniu, iż wszystkie państwa związane postanowieniami rozporządzenia (w szczególności wszystkie państwa członkowskie UE) przestrzegają praw podstawowych Unii Europejskiej. Wychodząc z tego założenia, wszystkie te państwa traktują siebie nawzajem jako kraje bezpieczne. Pojawia się jednak pytanie, czy domniemanie przestrzegania praw fundamentalnych można obalić, a jeśli tak, to w jaki sposób? W tym zakresie dostrzec można różnice w podejściu orzeczniczym europejskich trybunałów: Europejskiego Trybunału Praw Człowieka w Strasburgu i Trybunału Sprawiedliwości Unii Europejskiej w Luksemburgu (TSUE).

Autorka omawia stanowiska wyrażone w orzecznictwie obydwu trybunałów i dochodzi do wniosku, że podzielają one pogląd, iż wspomniane wyżej domniemanie może być obalone w celu zapewnienia, by osoby ubiegające się o ochronę międzynarodową nie były odsyłane na terytorium, na którym mogłoby grozić im nieludzkie lub poniżające traktowanie. Jednakże trybunały różnią się w ocenie 
okoliczności, jakie muszą zostać stwierdzone, by doszło do obalenia domniemania. ETPC kładzie nacisk na indywidualne zagrożenie dla konkretnej osoby w razie powrotu do państwa odpowiedzialnego zgodnie z kryteriami dublińskimi, zaś TSUE koncentruje się na ogólnym stanie systemu azylowego w danym państwie. W ujęciu tego drugiego organu, dążącego do zachowania zasady wzajemnego zaufania, jedynie stwierdzenie poważnych i systemowych braków może przełamać domniemanie poszanowania przez państwa członkowskie praw fundamentalnych. Autorka, po przeprowadzeniu wnikliwej analizy orzecznictwa w omawianym zakresie, stwierdza, że taka restrykcyjna interpretacja nie jest zgodna z przepisami art. 52 i 53 Karty Praw Podstawowych.

W związku z powyższym rodzą się kolejne pytania, rozważane w ostatniej części artykułu, a mianowicie: jakie obowiązki spoczywają na państwie, pod którego jurysdykcją znajduje się osoba, której wniosek w świetle kryteriów dublińskich winno rozpatrzeć inne państwo, niegwarantujące jednak praw fundamentalnych. $\mathrm{W}$ ocenie autorki pewne rozwiązanie tego problemu stanowi interpretacja przyjęta przez ETPC w sprawie Tarakhel. Zgodnie z tą interpretacją zakres obowiązków państwa zależy od skali ryzyka grożącego aplikantowi. Gdy zagrożenie nieludzkim lub poniżającym traktowaniem jest wysokie w związku z systemowymi problemami w państwie odpowiedzialnym, wnioskodawca nie może być do niego przekazany. W przypadku gdy zagrożenie nie wiąże się z systemowymi brakami, ale jedynie z okolicznościami indywidualnymi, państwo, na którego terytorium znajduje się aplikujący, powinno uzyskać od państwa odpowiedzialnego stosowne gwarancje, że wnioskodawca będzie miał zapewnione właściwe warunki pobytu i dostęp do sprawiedliwej oraz efektywnej procedury azylowej. Wówczas dopiero może przekazać wnioskodawcę do państwa odpowiedzialnego.

Artykuł kończy konkluzja, że interpretacja powyższa zapewni poszanowanie zarówno zasady wzajemnego zaufania, jak i zasady non-refoulement i z tego powodu stanowić może praktyczny sposób realizacji polityki azylowej w zgodzie z przepisami Karty Praw Podstawowych. 